\title{
ANALISIS FRAMING PEMBERITAAN KOMPAS.COM TENTANG COVID-19 DI DKI JAKARTA
}

\author{
Rosida Simatupang \\ Universitas Budi Luhur, Jakarta - Indonesia \\ rosidasimatupang11@gmail.com
}

\begin{abstract}
Handling the Covid-19 virus outbreak in Indonesia since its emergence in March 2020 requires targeted policies both at the national and regional levels. The spread and handlers of the Covid-19 virus are a concern because the number is increasing dramatically. Jakarta as the capital of the country becomes a parameter for other regions in the handling of Covid-19. The outbreak of global pandemic status certainly attracted the attention of the mass media, including online media. With the ability to construct reality, online media has the power to process facts and data in such a way, in accordance with its interests. Researchers will analyze the news with framing analysis to find out the construction of Kompas.com in the news of COVID-19 in DKI Jakarta.This study aims to analyze how framing Kompas.com news about COVID-19 in DKI Jakarta. The research method used is qualitative with framing analysis of Pan and Kosicki models. The results of the study suggest that Kompas.com tends to support governor Anis Baswedan's policy of quarantine the DKI Jakarta area, then Kompas.com does not meet the principle of accuracy in running disaster journalism because it does not verify data.
\end{abstract}

Keywords: disaster journalism; framing analysis; media reality construction; kompas.com; covid-19

\begin{abstract}
Abstrak
Penanganan wabah virus Covid-19 di Indonesia sejak munculnya pada bulan Maret 2020 membutuhkan kebijakan yang terarah baik di tingkat nasional maupun daerah. Penyebaran dan penangan virus Covid-19 menjadi perhatian sebab jumlahnya meningkat drastis. Jakarta sebagai ibukota negara menjadi parameter bagi daerah lain dalam penangan Covid-19. Peristiwa wabah berstatus pandemi global ini tentu menarik perhatian media massa, termasuk media online. Dengan kemampuan melakukan konstruksi realitas, media online memiliki kuasa mengolah fakta dan data sedemikian rupa, sesuai dengan kepentingannya. Peneliti akan menganalisis pemberitaan tersebut dengan analisis framing untuk mengetahui konstruksi Kompas.com dalam pemberitaan COVID-19 di DKI Jakarta.Penelitian ini bertujuan untuk menganalisis bagaimana framing pemberitaan Kompas.com tentang COVID-19 di DKI Jakarta. Metode penelitian yang digunakan adalah kualitatif dengan analisis framing model Pan dan Kosicki. Hasil penelitian menjukkan bahwa Kompas.com cenderung mendukung kebijakan Gubernur Anis Baswedan melakukan karantina wilayah DKI Jakarta, selanjutnya Kompas.com tidak memenuhi prinsip akurasi dalam menjalankan jurnalisme bencana karena tidak melakukan verifikasi data.
\end{abstract}

Kata Kunci: jurnalisme bencana; analisis framing; konstruksi realitas media; kompas.com; covid-19

\section{PENDAHULUAN}

Dunia diguncang wabah Corona Virus Disease 2019 (COVID-19) yang bermula terjadi di kota Wuhan, Cina, di akhir tahun 2019. Pada 11 Maret 2020, WHO menyatakan, wabah COVID-19 sebagai pandemi global. Dalam Kamus Besar Bahasa Indonesia, pandemi diartikan sebagai wabah yang berjangkit serempak dimana-mana meliputi geografi yang luas. Selain itu penyebaran virus begitu cepat dan di luar kendali, serta memiliki garis infeksi yang berkelanjutan.

Peningkatan angka yang terinfeksi dan meninggal karena COVID-19 melesat semenjak pemerintah mengumumkan kasus pasien pertama pada tanggal 2 Maret 2020. 
Oleh karena itu, pemerintah Indonesia menyatakan wabah ini sebagai bencana nasional. Menurut Nazaruddin, ketika sebuah bencana terjadi, masyarakat selalu ingin tahu tentang berbagai hal mengenai bencana tersebut, misalnya tentang penyebab, korban, kerugian, dampaknya secara luas, penanggulangan, dan lainnya. Dalam situasi ketidakpastian yang ditimbulkan bencana, kebutuhan masyarakat terhadap berita-berita bencana akan meningkat tajam, dan ini menggerakkan liputan bencana yang intensif dari media massa. Dalam posisi tersebut, media memegang kuasa yang besar karena masyarakat menggantungkan sumber informasi tentang bencana dari media

Potensi kuasa yang besar tersebut kurang dimanfaatkan oleh berbagai media di Indonesia. Media-media di Indonesia masih menunjukkan euforia saat memberitakan bencana. sebagian besar media hanya mengeksploitasi bencana sebagai "kisah satir yang menghibur', dengan berbagai praktik dramatisasi, demi kepentingan akumulasi modal semata. Dalam kacamata bisnis media, bencana adalah 'blessing in disquise', menjadi sumber informasi yang tidak pernah kering dengan kandungan nilai berita yang tinggi

Dalam fase-fase awal paskabencana seringkali ada kabar angin yang sangat dramatis, misalnya angka kematian yang dibesar-besarkan, ketakutan dan kekacauan sosial. Perspektif atau cara pandang yang digunakan oleh wartawan ketika menyeleksi isu dan menulis berita itu, menurut Eriyanto pada akhirnya menentukan fakta apa yang diambil, bagian mana yang ditonjolkan dan dihilangkan, dan hendak dibawa kemana berita tersebut (Eriyanto, 2002).

Pada pemebritaan media sebagaimana pada Senin, 30 Maret 2020, Gubernur DKI Jakarta Anies Baswedan menggelar konferensi pers di Balai Kota tentang COVID-19 yang melanda wilayahnya. Konferensi pers itu kemudian diberitakan oleh Kompas.com. Pemberitaan di Kompas.com menarik untuk diteliti, karena Kompas.com menerbitkan lima berita hasil dari konferensi tersebut, di hari
Senin itu juga. Ini menunjukkan perhatiannya yang besar tentang Covid-19 di Jakarta, sehingga peristiwa ini ditonjolkan (emphasize).

Untuk memperkuat penelitan ini, maka digunakan kerangka teoritis dan kerangka konseptual. Salah satunya Teori Konstruksi Realitas Sosial. Menurut Peter Berger dan Thomas Luckman (1996) bahwa realitas sosial bukan sesuatu yang terjadi secara alami. Realitas sosial merupakan bentukan, sengaja dibuat untuk kepentingan tertentu. Realitas yang tercipta sepenuhnya bersifat subyektif, yaitu realitas berasal dari pemaknaan dari dalam dirinya sendiri. Dalam memandang konstruktivisme, realitas berwajah plural sesuai kadar wawasannya masing-masing. Kondisi dan tingkat sosial yang akan mempengaruhi daya kritis, pemahaman dan cara menafsirkan sebuah realitas sosial. Semakin tinggi wawasan atau pendidikan yang ditempuh, maka akan semakin luas dan dalam pula pemahaman realitasnya (Basrowi dan Sadikin, 2002:194).

Teori konstruksi sosial lalu berkembang ke arah konstruksi media. Pada tataran ini sudut pandang media memainkan perannya sebagai pemilik kuasa untuk mengontruksi sedemikian rupa fakta serta data. Secara konkrit, media mempunyai kuasa penuh untuk mempublikasikan berita-berita yang dipilihnya, melalui proses pengolahan, sesuai framing dan kepentingannya masingmasing.

Media dapat menonjolkan aspek-aspek tertentu, memilih narasumber sesuai sudut pandangnya, atau menyembunyikan pesanpesan tertentu. Dengan demikian, harapan yang ingin dicapai media, bukan hanya soal keberhasilan mempublikasikan isu-isu penting, namun juga bagaimana isu yang semula tidak dianggap penting bisa menjadi penting, begitupun sebaliknya (Bungin, 2008).

Media melakukan tiga hal untuk menciptakan realitas sesuai keinginannya. Pertama, penggunaan framing pemberitaan, yaitu bagaimana sebuah media membingkai sebuah kejadian dari kacamata kepentingannya. Kedua, memakai simbolsimbol untuk menegaskan framingnya. 
Bahkan, media juga turut beropini secara tidak langsung melalui perwakilan narasumber yang sengaja dipilih atau diperbanyak kuantitasnya. Ketiga, melakukan seleksi isu berdasarkan tingkat rating ataupun skala prioritas penting atau tidak penting (Eriyanto, 2008:2).

Berita yang muncul di media merupakan salah satu variasi penyampaian realitas kepada khalayak. Berita yang tersaji bukanlah realitas objektif tapi realitas subjektif yang kemudian hadir ke pembaca setelah melalui proses konstruksi (subjectivelyconstructed reality). Menurut pandangan konstruktivis, berita pada media massa adalah hasil konstruksi sosial di mana selalu melibatkan pandangan, ideologi, dan nilai-nilai dari wartawan dan media itu sendiri. Bagaimana realitas itu dijadikan berita sangat tergantung pada bagaimana fakta itu dipahami dan dimaknai (Eriyanto 2002, 26).

Konseptual yang relevan dengan penelitian ini istilah jurnalistik sebenarnya berasal dari bahasa Perancis yakni kata dujour yang berarti "hari", sedangkan journal bermakna "catatan harian" (Sutedjo dan Sumarlam, 2008:21). Pengertian jurnalisme tidak berbeda jauh dengan pengertian jurnalistik, yakni sebuah aliran atau paham jurnalistik. Catatan harian yang dimaksud di dalam dunia jurnalistik adalah produk berita yang proses pengolahannya melalui kerangka sistematis mulai dari pencarian berita oleh wartawan sampai publikasi. Dapat disimpulkan, pengertian jurnalisme bencana adalah sebuah aliran atau paham jurnalistik yang meliputi kejadian bencana.

Jurnalisme bencana adalah genre baru jurnalistik yang sangat penting bagi mediamedia di Indonesia. Pertama, secara geologis maupun sosiologis Indonesia adalah negeri rentan bencana. Kedua, media massa selalu (dan pasti) akan memberitakan setiap peristiwa bencana yang terjadi, bahkan menjadi headline ataupun mengisi waktuwaktu prime time. Ketiga, masyarakat menggantungkan pengetahuannya tentang bencana kepada informasi yang disajikan media massa. Keempat, bencana selalu diikuti ketidakpastian dan kesimpangsiuran informasi, yang seringkali menyesatkan, karena itu media massa menjadi tumpuan utama untuk menyajikan informasi yang akurat.

Padahal, menurut UU No. 40/1999

Tentang Pers Pasal 3 mengatakan bahwa peran dan fungsi pers adalah sebagai media informasi, pendidikan, hiburan dan kontrol sosial. Media harus memenuhi ruang publik dengan informasi yang akurat, terpercaya, obyektif, jujur dan tidak manipulative dalam pemberitaaan. bahwa pemberitaan di media massa bisa menjadi bencana tersendiri di bidang informasi. (Arif, 2010:123).

Peristiwa dipahami dengan bentukan tertentu. Hasilnya pemberitaan media pada sisi tertentu atau wawancara dengan orang-orang tertentu. Semua elemen tersebut tidak hanya bagian dari teknik jurnalistik tetapi menandai bagaimana sebuah peristiwa dimaknai dan di tampilkan (Eriyanto, 2002: 8).

Framing adalah metode untuk melihat cara bercerita media atas peristiwa. Cara bercerita itu tergambarkan pada cara melihat realitas yang dijadikan berita oleh media. Cara melihat ini berpengaruh pada hasil akhir dari konstruksi realitas. Analisis framing sebagai analisis yang dipakai untuk melihat bagaimana media mengkonstruksi realitas. Analisi framing juga untuk melihat bagaimana peristiwa dipahami dan dibingkai oleh media (Eriyanto, 2001: 9).

Ada dua esensi utama dari framing, yaitu pertama, bagaimana peristiwa dimaknai. Ini berhubungan dengan bagian mana yang diliput dan bagian mana yang tidak diliput. Kedua, bagaimana fakta ditulis, Hal ini berhubungan dengan pemakaian kata, kalimat atau gambar untuk mendukung gagasan. Framing, terutama melihat bagaimana pesan/peristiwa dikonstruksi oleh media atau bagaimana wartawan mengkonstruksi peristiwa dan menyajikannya kepada khalayak pembaca Berita yang ada di media massa saat ini, bukan sekedar menyampaikan 
tetapi juga menciptakan makna (Eriyanto, 2012: xii). Para awak media seringkali mengemas serta membingkai aspek tertentu dari peristiwa lewat bantuan kata, aksentuasi kalimat, gambar dan perangkat lainnya (Eriyanto, 2012: 11). Penekanan pada aspek tertentu dari suatu realitas, akan membuat bagian tertentu menjadi lebih bermakna, lebih mudah diingat, dan lebih mengena dalam pikiran masyarakat (Sobur, 2002: 164).

Dalam perspektif komunikasi, analisis framing dipakai untuk membedah cara-cara atau ideologi media atau mengkonstruksi fakta. Analisis ini mencermati strategi seleksi, penonjolan dan pertauatan fakta ke dalam berita agar lebih bermakna, lebih menarik, lebih berarti atau lebih diingat, untuk menggiring interpretasi khalayak sesuai perspektifnya. Framing adalah pendekatan untuk mengetahui bagaimana perspektif atau cara pandang wartawan ketika menyeleksi isu dan menulis berita. (Sobur, 2004:162).

Pan \& Kosicki menyatakan, framing dapat dipelajari sebagai suatu strategi untuk memproses dan mengontruksi wacana berita atau sebagai karakteristik wacana itu sendiri. Proses framing berkaitan erat dengan rutinitas dan konvensi profesional jurnalistik. Proses framing tidak dapat dipisahkan dari strategi pengolahan dan penyajian informasi dalam presentasi media.

Dengan kata lain, proses framing merupakan bagian integral dari proses redaksional media massa. Dominasi sebuah frame dalam wacana berita bagaimanapun berkaitan dengan proses produksi berita yang melibatkan unsur seperti reporter, redaktur dan lainnya. Analisis framing tidak melihat presentasi media sebagai sesuatu yang bebas nilai, karena banyak faktor yang memengaruhinya.

Penelitian yang dilakukan oleh Hartina Sanusi (2018), pada peneletian ini terlihat peneliti untuk menelaah lebih jauh sebuah diskursus peran jurnalis di masyarakat terkait isu kebencanaan. Menurutnya kajian ini sangat relevan mengingat sebagian besar wilayah Indonesia termasuk dalam kategori potensi rawan bencana cukup tinggi. Sehingga, isu kebencanaan masih menjadi salah satu isu yang dianggap penting bagi khalayak dan media.

Pendekatan yang paling mudah untuk memahami studi dan praktik jurnalisme adalah dengan melihat jurnalisme sebagai suatu profesi, suatu pekerjaan yang berhubungan dengan pemberitaan di media massa. Di Indonesia, profesi jurnalis lebih dirinci dalam Undang-undang No. 40 tentang Pers tahun 1999. Konsep yang digunakan dalam penelitian ini adalah konsep jurnalis dan jurnalis bencana.

Persamaan dengan penelitian saat ini terletak pada objek pemberitaan bencana dan konsep jurnalis bencana. Tetapi perbedaannya juga sangat terlihat dari teori dan konsep serta media yang diteliti sehingga hasilnya juga berbeda.

Selanjutnya penelitian kedua Wahyuni, Hermin. I. (2008) penelitian ini ingin menangkap kecenderungan umum ataupun fenomena makro media dan bencana, maka metode Framing yang diterapkan didesain sedemikian rupa untuk mencapai tujuan tersebut. Framing akan dilakukan secara umum melalui pengamatan pada obyek penelitian yaitu berita yang muncul di media cetak baik surat kabar nasional dan daerah, termasuk di dalamnya yang muncul di internet, serta pemberitaan mengenai bencana di media elektonik televisi. Periode penelitian sangat dipengaruhi oleh bencana alam gempa bumi yang terjadi di Yogyakarta 27 Mei 2006 lalu. Fokus penelitian nantinya tidak sekedar peristiwa gempa bumi tersebut namun juga peristiwa bencana lainnya yang terjadi setelah bulan Mei tersebut hingga sekitar Maret 2007.

Persamaan dengan penelitian saat ini terletak pada objek soal bencana yang terjadi. Tetapi perbedaan pada penelitian terletak pada teori, konsep serta media yang digunakan, sebab penelitian tersebut lebih fokus pada pemberitaan surat kabar dan televisi. Sehingga dari sisi kebaruan saat ini peneliti fokus pada wabah Covid-19 yang masih terjadi di Indonesia.

Peneliti mengambil media online Kompas.com dalam penelitian ini, karena 
Kompas.com masuk rating 10 media online di Indonesia versi Alexa, 3 Juli 2020 (Alexa.com, Juli 2020). Sebagai media online yang masuk dalam rating 10 besar versi Alexa, Kompas.com memiliki jumlah khalayak pembaca yang besar sehingga dapat mempengaruhi opini publik yang dominan di masyarakat. Peneliti akan menganalisis pemberitaan tersebut dengan analisis framing untuk mengetahui konstruksi Kompas.com dalam pemberitaan COVID-19 di DKI Jakarta. Adapun tujuan dari penelitian ini adalah untuk mendapatkan gambaran bagaimana framing pemberitaan Kompas.com tentang COVID-19 di DKI Jakarta.

\section{METODOLOGI PENELITIAN}

Untuk menggambarkan proses seleksi serta penonjolan aspek tertentu dari realitas oleh media, digunakan metode penelitian analisis framing model Zhongdang Pan dan Gerald M. Kosicki. Framing dapat dipandang sebagai penempatan informasi dalam konteks yang khas sehingga isu tertentu mendapatkan alokasi lebih besar daripada isu lain. Metode ini melihat bagaimana seseorang memaknai suatu peristiwa dapat dilihat dari perangkat tanda yang dimunculkan dalam teks. Wartawan menggunakan kata, kalimat, lead, hubungan antarkalimat, foto, grafik, dan perangkat lain untuk membantu dirinya mengungkapkan pemaknaan mereka sehingga dapat dipahami (Eriyanto, 2012: 293). Pendekatan yang dilakukan kualitatif dengan paradigma konstruktivis, yakni memahami susunan teks bukan hanya sekedar susunan, namun ada maksud-maksud tertentu di dalamnya.

Perangkat analisis framing model Pan dan Kosicki dibagi ke dalam 4 perangkat, yaitu: Sintaksis, dalam pengertian umum adalah susunan kata atau fase dalam kalimat. Dalam wacana berita sintaksis merujuk pada pengertian susunan dan bagian berita seperti headline, lead, latar informasi, sumber, penutup dalam satu kesatuan teks berita secara keseluruhan.

Bila dijabarkan maka Model Pan dan Kosicki dapat dianalisis dari: 1) Skrip, adalah laporan berita sering disusun sebagai suatu cerita bentuk umum dari struktur skrip adalah pola $5 \mathrm{~W}+1 \mathrm{H}$ (who, what, when, where, why dan how); 2)Tematik, yaitu alat analisis untuk melihat bagaimana fakta ditulis, kalimat yang dipakai, serta menempatkan dan menulis sumber ke dalam teks berita secara keseluruhan. Dalam perangkat tematik terdapat beberapa elemen yang diamati, diantaranya adalah koherensi, pertalian atau jalinan antar kata, dan proposisi atau kalimat; 3) Retoris, struktur retoris dari wacana berita menggambarkan pilihan gaya atau kata yang dipilih oleh wartawan untuk menekankan arti yang ingin ditonjolkan oleh wartawan. Ada beberapa elemen struktur retoris yang dipakai oleh wartawan, yang paling penting adalah leksikon, pemilihan dan pemakaian kata- kata tertentu untuk menandai atau menggambarkan peristiwa.

Tabel 1. Kerangka Framing Pan dan Kosicki

\begin{tabular}{|c|c|c|}
\hline \multirow{2}{*}{$\begin{array}{l}\text { PERANGKAT } \\
\text { FRAMING } \\
\text { SINTAKSIS, cara } \\
\text { wartawan menyusun } \\
\text { fakta }\end{array}$} & \multicolumn{2}{|r|}{ UNIT YANG DIAMATI } \\
\hline & Skema berita & $\begin{array}{l}\text { Headline, lead, latar informasi, } \\
\text { sumber kutipan, pernyataan, penutup }\end{array}$ \\
\hline $\begin{array}{l}\text { SKRIP, cara } \\
\text { wartawan } \\
\text { mengisahkan fakta }\end{array}$ & $\begin{array}{l}\text { Kelengkapan } \\
\text { berita }\end{array}$ & $\begin{array}{l}5 \mathrm{~W} \text { (who, what, when, where, why) + } \\
1 \mathrm{H}(\text { how })\end{array}$ \\
\hline $\begin{array}{l}\text { TEMATIK, cara } \\
\text { wartawan menulis fakta }\end{array}$ & $\begin{array}{l}\text { Detail, detil, } \\
\text { koherensi, bentuk } \\
\text { kalimat, kata } \\
\text { ganti }\end{array}$ & $\begin{array}{l}\text { Paragraf, proposisi, kalimat, hubungan } \\
\text { antaralimat. }\end{array}$ \\
\hline
\end{tabular}




$\begin{array}{lllll}\begin{array}{l}\text { RETORIS, cara } \\ \text { wartawan } \\ \text { menekankan fakta }\end{array} & \begin{array}{l}\text { Leksikon, grafis, } \\ \text { metafor }\end{array} & \begin{array}{l}\text { Kata, } \\ \text { grafik }\end{array} & \begin{array}{l}\text { idio } \\ \mathrm{m},\end{array} & \text { gambar/foto, } \\ & & & \end{array}$

(Sumber: Eriyanto, 2002:295)

Pada tabel 1, keempat perangkat analisis framing model Pan dan Kosicki tersebut memberikan gambaran lebih jelas apa itu framing. Hal ini membantu peneliti melihat bagaimana konstruksi realitas yang dibangun oleh wartawan Kompas.com dalam pemberitaan COVID-19 di DKI Jakarta.

HASIL DAN PEMBAHASAN
Subjek penelitian ini mengambil sumber dari Kompas.com, dengan objek penelitian berupa teks berita yang terbit di Kompas.com tentang COVID-19 di DKI Jakarta berdasarkan hasil konferensi pers Gubernur Anies Baswedan pada Senin, 30 Maret 2020. Dari hasil konferensi pers tersebut, Kompas.com memuat 5 (lima) berita, yang terbit Senin, 30 Maret 2020.

\begin{tabular}{lll}
\multicolumn{4}{c}{ Tabel 2. Daftar Berita Kompas.com tentang COVID-19 di DKI Jakarta } \\
\hline $\begin{array}{l}\text { NO } \\
\text { - WAKTU TERBIT }\end{array}$ & \multicolumn{3}{c}{ JUDUL BERITA } \\
\hline $\mathbf{1}$ & Senin, 30 Maret 2020 & $\begin{array}{l}\text { Anies: 283 Jenazah Dimakamnkan dengan Protokol } \\
\text { Pemulasaran Jasad Pasien Covid-19 }\end{array}$ \\
\hline $\mathbf{2}$ & Senin, 30 Maret 2020 & $\begin{array}{l}\text { Suaranya Bergetar Sebut 283 Warga Dimakamkan, Anies: } \\
\text { Itu Warga Kita yang Bulan Lalu Sehat }\end{array}$ \\
\hline $\mathbf{3}$ & Senin, 30 Maret 2020 & $\begin{array}{l}\text { Anies Minta Pusat Terapkan Karantina Wilayah di Jakarta, } \\
\text { dengan Syarat... }\end{array}$ \\
\hline $\mathbf{4}$ & Senin, 30 Maret 2020 & $\begin{array}{l}\text { Kewenangannya Terbatas, Anies Harap Ada Ketetapan } \\
\text { untuk Penegakan Social Distancing. }\end{array}$ \\
\hline $\mathbf{5}$ & Senin, 30 Maret 2020 & $\begin{array}{l}\text { Lebih Besar dari Angka Kematian Nasional, 283 Jenazah di } \\
\text { DKI Dimakamkan dengan Protokol Covid-19 }\end{array}$ \\
\hline
\end{tabular}

(Sumber: hasil olahan penulis, 2020)

Pada tabel 2, dari analisis lima berita Kompas.com tentang Covid-19 di Jakarta, dapat ditemukan konstruksi Kompas.com sebagai berikut:

\section{Berita berjudul "Anies: 283 Jenazah Dimakamkan dengan Protokol Pemulasaran Jasad Pasien Covid-19"}

Dari struktur Sintaksis, judul Kompas.com ini dapat dianggap data aktual jumlah yang meninggal karena Covid-19 di DKI Jakarta, yatu 283 orang. Lalu ditegaskan kembali dalam lead, sebagai berikut:

"Gubernur DKI Jakarta Anies Baswedan mengatakan, Dinas Pertamanan dan Hutan Kota DKI Jakarta mencatat 283 pemakaman jenazah dengan protokol pemulasaran jasad pasien Covid-19 sejak awal Maret 2020. Protap Covid-19, di antaranya bahwa jenazah dibungkus dengan plastik, menggunakan peti, dan harus dimakamkan kurang dari 4 jam, dan petugasnya menggunakan APD (alat pelindung diri)," kata Anies dalam konferensi pers di Balaikota, Senin (30/3/2020).”.

Pada isi berita juga, dengan kutipan sebagai berikut, "Sejak tanggal 6 (Maret 2020), itu mulai ada kejadian pertama, sampai tanggal 9 (Maret 2020) itu udah 283 kasus, " ucap dia. Dari judul, lead dan isi berita dapat disimpulkan, ada 283 warga meninggal karena Covid-19. Kompas.com menggunakan pernyataan Gubernur DKI Jakarta Anies Baswedan pada judul dan lead beritanya, berarti Kompas.com menganggap pernyataan Anies penting itu penting. Dalam hal ini, Kompas.com menggunakan sudut pandang Anies tentang Covid-19 di Jakarta.

Pada isi berita berikutnya ada pernyataan Anies 
kemudian,

"Anies mengungkapkan, tak semua dari jenazah itu merupakan pasien yang telah terkonfirmasi positif Covid-19. Ini adalah mungkin mereka-mereka yang belum sempat dites (Covid-19), oleh karenanya belum bisa disebut sebagai positif, atau sudah dites tapi belum ada hasilnya," ujar dia.

Jika membaca pernyataan ini, mungkin saja data 283 yang dimakamkan dengan protokol Covid-19 itu benar terjadi. Namun apakah 283 yang meninggal itu semuanya karena Covid-19? Sepertinya, masih "mungkin". Dengan demikian, penyebab 283 jenazah yang dimakamkan itu, belum bisa disebut karena positif Covid-19. Korban bisa saja meninggal karena sebab lain, kecelakaan, sakit lain, atau bisa saja para korban itu sudah tes, tapi hasilnya belum ada. Bisa jadi jumlah korban bukan sebesar 283 orang, bahkan kurang dari 283 orang.

Sebagai narasumber utama, pernyataan Gubernur Anies mengisi mulai dari judul, lead, isi berita hingga penutup. Adapun kutipan narasumber yang lain, adalah rilis Pemprov DKI Jakarta. Rilis tersebut menyampaikan data korban meninggal akibat Covid-19 sebanyak 67 orang. Padahal, Pemprov DKI Jakarta adalah juga perwakilan dari Gubernur DKI Jakarta.

Data yang disampaikan dalam rilis berbeda jauh dengan data yang disampaikan Gubernur Anies, malah kontradiktif. Kompas.com menampilkan dua kutipan sumber dari sumber yang sama, di hari yang sama, namun dengan data yang berbeda. Berikut kutipan kalimat dalam beritanya, "Senin (30/3/2020), Pemprov DKI Jakarta merilis total terdapat 701 pasien positif Covid-19, dengan 48 pasien berhasil sembuh. Namun, 67 pasien di antaranya meninggal dunia.".

Dengan memakai model piramida terbalik, Kompas.com menempatkan fakta yang dianggap penting di awal berita. Tiga paragraf pertama pernyataan Gubernur Anies tentang 283 korban Covid-19, sedangkan data Kementerian Kesehatan dan data rilis Pemprov DKI Jakarta diletakkan di paragraf 7 dan 9 dari 11 paragraf keseluruhan berita. Ini artinya, pernyataan Anies tentang 283 korban Covid-19 dinilai lebih tinggi daripada data Kementerian Kesehatan dan data yang dirilis Pemrpov DKI Jakarta. Kompas.com ingin menyandingkan dengan data korban dari sumber lain, namun besarnya angka 283 korban tetap digirng Kompas.com hingga penutup berita.

Dalam struktur Skrip, unsur $5 \mathrm{~W}+1 \mathrm{H}$ sudah lengkap. Tetapi peneliti mengamati, unsur kelengkapan teks berita yang muncul hanya mendukung tema atau konstruksi dari Kompas.com itu sendiri. Seharusnya Kompas.com memunculkan data atau keterangan tempat tinggal 283 korban tersebut. Kompas.com juga tidak menyajikan data penyebab kematian 283 korban, bagaimana kejadiannya, dan seterusnya. Padahal, dalam jurnalisme bencana, informasi tentang tempat tinggal korban, apa penyebab kematian serta dimana saja korban dimakamkan, menjadi penting untuk diketahui. Pengetahuan masyarakat tentang bencana sangat tergantung terhadap informasi akurat yang disajikan media massa (Jurnal Komunikasi 2007, hal.165).

Dari Struktur Tematik, penekanannya pada 283 korban Covid-19 di Jakarta. Tiga paragraf di awal, saling berhubungan dan menguatkan. Namun, dua paragraf selanjutnya, seperti mengaburkan kesimpulan pembaca bahwa 283 korban yang dimakamkan dengan protokol Covid-19 itu adalah benar korban Covid-19. Lalu, Kompas.com di paragraf selanjutnya, kembali menggiring emosi pembaca ke data 283 korban Covid-19, sehingga dikatakan data ini penting dan mengkhawatirkan dengan kondisi Jakarta sebagai pusat pandemic Covid19 Indonesia. Malah, terkesan mendramatisir. Jumlah korban Covid-19 seperti ditarik ulur. Kompas.com cenderung mengarahkan khalayak terhadap data yang disampaikan di awal berita, seperti kalimat berikut, "Data ini perlu mengiringi data-data jumlah kasus harian Covid-19 yang setiap hari diumumkan oleh Kementerian Kesehatan RI.”

Kompas.com tidak menjelaskan lebih lanjut data Kementerian Kesehatan. Kompas.com tidak melakukan verifikasi kepada Kementerian Kesehatan terkait 
pernyataan Anies. Masih tentang data korban, peneliti juga tidak melihat penyajian data tentang korban yang meninggal akibat Covid19 yang diperoleh Kompas.com dari rilis Pemprov DKI Jakarta. Bukankah Gubernur Anies adalah Pemprov DKI Jakarta? Kenapa Gubernur Anies dalam konferensi pers tersebut tidak menggunakan data dari Pemprov DKI Jakarta? Pertanyaan lainnya, siapakah yang dimaksud dengan Pemprov DKI Jakarta yang rilisnya dikutip oleh Kompas.com?

Dari analisis struktur Retoris, Kompas.com memakai kalimat "amat mengkhawatirkan" dalam perangkat Leksikon. Munculnya kalimat "amat menghkhawatirkan" dalam paragraf 6 dan paragraf 8, untuk menekankan bahwa kondisi DKI Jakarta kritis dan gawat. Ada juga pemakaian angka "283" pada judul, lead, dan isi berita, menunjukan ada penekanan yang memberi makna keterangan tersebut penting untuk disampaikan. Kata "episentrum" untuk menunjukkan bahwa Jakarta sebagai Ibukota adalah pusat pandemi Indonesia. Kata "mengiringi" memiliki makna mengikuti (menyertai) dengan maksud mengawal, yang memberi pengertian mengawal data dari Kementerian Kesehatan. Kata "instruksi" berarti perintah dan arahan untuk melakukan suatu pekerjaan atau melaksanakan suatu tugas, yang menggambarkan perintah Gubernur DKI Jakarta Anies Baswedan yang tegas dan wajib dilakukan untuk menekan jumlah korban karena Covid-19. Pemakaian kata "instruksi" setelah kata "menggaungkan" menekankan, bahwa warga Jakarta harus diperintah dengan suara yang besar agar tidak kemana-mana, tetap di rumah.

\section{Berita berjudul "Suaranya Bergetar Sebut 283 Warga Dimakamkan Anies: Itu Warga Kita yang Bulan Lalu Sehat".}

Secara substansi seluruh isi berita kedua Kompas.com ini sama dengan berita sebelumnya. Hanya ada penekanan di kata "bergetar" dan "statistik". Pada berita keduanya, Kompas.com menerbitkan berita dengan judul "Suaranya Bergetar Sebut 283 Warga Dimakamkan Anies: Itu Warga Kita yang Bulan Lalu Sehat”.

Dari analisis Sintaksis, pernyataan Gubernur DKI Jakarta Anies Baswedan yang muncul dalam judul berita dan leadnya, memperlihatkan bahwa Kompas.com menggunakan sudut pandang Anies tentang Covid-19 di Jakarta. Pemakaian kata "Suaranya bergetar", "Dimakamkan" dan "283 Warga yang bulan lalu sehat" menggambarkan kondisi Jakarta terkini yang sangat mencekam.

Menurut peneliti, judulnya sangat dramatis, "Suara Gubernur DKI Jakarta Anies Baswedan sampai bergetar sebut 283 warga yang dimakamkan". Pemakaian kata "bergetar" pada judul berita untuk mendorong pembaca membaca berita Kompas.com tersebut. Kata "bergetar" juga dipakai dalam lead beritanya, "Suara Gubernur DKI Jakarta Anies Baswedan mendadak bergetar ketika ia menyampaikan data mengenai jumlah korban meninggal dunia yang harus dimakamkan sesuai protokol pemulasaran jasad pasien Covid-19". Kalimat ini memberi makna, Anies tak kuasa menahan perasaannya ketika dia meyebutkan angka korban, sehingga suaranya mendadak bergetar.

Menurut peneliti, lead berita juga terkesan dramatis. Melalui judul dan lead, dapat disimpulkan bahwa 283 jenasah tersebut adalah korban Covid-19 dan situasi Jakarta mencekam. Tak cukup sampai lead, kutipan sumber berita, semakin memberi makna bahwa korban yang dimakamkan adalah benar korban positif Covid-19, yakni; "Anies menyebutkan, Dinas Pertamanan dan Hutan Kota DKI Jakarta mencatat 283 jasad dikebumikan kurang dari 4 jam selepas wafat, dibungkus plastik, menggunakan peti, dan petugas pemakamannya mengenakan alat pelindung diri (APD)."

Judul dan lead, juga kutipan narasumber memberi makna, betapa mencekamnya suasana Jakarta. Masyarakat yang sekarang sehat, belum tentu selamat dari Covid-19.

Kelanjutan dari lead, Kompas.com mengutip pernyataan Anies sebagai berikut: "jangan pandang angka ini sebagai angka statistik". Sayangnya, Kompas.com tidak mengejar Gubernur Anies untuk menjelaskan apa yang dimaksud dengan angka statistik. 
Pernyataan Anies selanjutnya sebagai berikut; (Data) 283 itu bukan angka statistik. Itu adalah warga kita yang bulan lalu sehat... Yang bulan lalu bisa berkegiatan..." imbuh dia, dengan suara bergetar.

Anies bilang, belum tentu semua jasad yang dimakamkan itu merupakan pasien Covid19, sebagian mungkin masih berstatus suspect (dicurigai) Covid-19, karena belum dites atau hasil tes belum rilis saat meninggal.

Pernyataan Gubernur Anies yang ditampilkan Kompas.com dalam judul dan lead itu bertolak belakang dengan pernyataan Anies selanjutnya, yang mengatakan bahwa 283 warga yang meninggal itu belum tentu karena Covid-19.

Selanjutnya, mengenai kutipan sumber, sama seperti dalam berita pertamanya, Kompas.com juga menampilkan Gubernur Anies Baswedan sebagai narasumber utama, lalu rilis Pemprov DKI Jakarta, sebagai sumber lainnya. Namun, data korban yang disampaikan oleh kedua narasumber tersebut berbeda-beda. Dengan memosisikannya data Pemprov DKI Jakarta di 3 paragraf terakhir penutup berita, berarti data ini ini hanya sebagai informasi tambahan saja. Atau Kompas.com ingin menampilkan kepada khalayak, bahwa Gubernur Anies tidak memiliki data yang valid soal korban Covid-19. Dalam struktur Skrip, sama seperti berita pertama, unsur $5 \mathrm{~W}+1 \mathrm{H}$ sudah lengkap, namun pemilihan unsur-unsur kelengkapan teks berita, hanya mendukung konstruksi dari Kompas.com itu sendiri.

Demikian juga dari analisis Tematik, peneliti melihat ada kesamaan dengan berita pertama. Tiga paragraf di awal, saling berhubungan dan menguatkan. Namun empat paragraf selanjutnya, seperti mengaburkan kesimpulan pembaca bahwa 283 korban yang dimakamkan dengan protokol Covid-19 itu adalah benar korban Covid-19. Perhatikan kutipan isi beritanya, "Anies bilang, belum tentu semua jasad yang dimakamkan itu merupakan pasien Covid-19, sebagian mungkin masih berstatus suspect (dicurigai) Covid-19, karena belum dites atau hasil tes belum rilis saat meninggal." Lalu, Kompas.com di paragraf selanjutnya, kembali menggiring emosi pembaca ke kondisi Jakarta yang amat mengkhawatirkan, yakni; "Keadaan tadi, menurut dia, menunjukkan bahwa kondisi Jakarta sebagai pusat pandemi Covid-19 di Indonesia masih amat mengkhawatirkan". Berangkat dari sana, Anies meminta warga DKI Jakarta serius melakukan pembatasan aktivitas, atau yang dikenal sebagai physical atau social distancing.

Penekanan terhadap situasi dan kondisi Jakarta yang amat mengkhawatirkan juga tercermin dari kalimat berikut ini, "Jangan sampai Dinas Pertamanan dan Hutan Kota yang mengurusi makam ini punya angka yang lebih tinggi lagi," lanjut Anies kembali dengan suara bergetar.

Sama seperti sebelumnya, dalam berita ini Kompas.com kembali menampilkan data rilis dari Pemprov DKI Jakarta. Munculnya data dari rilis Pemprov DKI Jakarta, membuat khalayak tidak memiliki kepastian tentang jumlah warga yang meninggal akibat Covid-19.

Dari struktur Retoris, idiom 'bergetar', terdapat di judul, lead,dan 2 kali di isi berita. Memberi makna bibir Anies bergerak berulangulang dengan cepat ketika menyampaikan jumlah korban, sehingga suara yang keluarpun bergetar. Pemilihan kata bergetar ini terkesan dramatis.

Begitu juga dengan penggunaan kalimat 'amat mengkhawatirkan' ingin menggambarkan kondisi Jakarta yang mencemaskan. Pemakaian kata 'amat' didepan kata 'mengkhawatirkan' memberikan pengertian, kekhawatiran yang luar biasa. Kata amat mengkhawatirkan dipergunakan sebanyak dua kali, di paragraph 6 dan 8. Pilihan angka '283' ditampilkan di judul, lead dan di isi berita. Penyampaian yang berulang, menunjukan ada penekanan, keterangan tersebut penting untuk disampaikan.

Kompas.com memberikan label positif Gubernur Anies Baswedan dengan memakai kata ganti "eks Menteri Pendidikan dan Kebudayaan RI", sebagai cara legitimasi simbolik bahwa sumber yang dikutip kredibel sehingga isi beritanya pun akan dinilai 
berbobot, mempresentasikan kecerdasan narausmber saat menyampaikan data dan saran.

\section{Berita berjudul "Anies Minta Pusat Terapkan Karantina Wilayah di Jakarta, dengan Syarat..."}

Dari stuktur sintaksis, jika dua berita Kompas.com sebelumnya menyampaikan jumlah korban Covid-19 di DKI Jakarta, namun pada berita ketiga ini, Kompas.com mengarahkan ke upaya karantina wilayah DKI Jakarta. Ini nampak dari judul beritanya "Anies Minta Pusat Terapkan Karantina Wilayah di Jakarta, dengan Syarat...".

Judul ini langsung membidik permintaan karantina ke pemerintah pusat. Kembali dalam judulnya beritanya, Kompas.com menggunakan pernyataan Anies. Ini berarti Kompas.com menggunakan sudut pandang pihak Anies Baswedan. Lead Kompas.com pun mengarahkan demikian,

"Gubernur DKI Jakarta Anies Baswedan telah meminta pemberlakuan karantina wilayah DKI Jakarta demi mencegah penyebaran virus corona tipe 2 (SARS-CoV-2) penyebab Covid19. Permintaan itu disampaikan Anies kepada pemerintah pusat".

Dari kalimat di atas, ancaman penyebaran virus Covid-19 merupakan ancaman keselamatan warga DKI Jakarta. Sebab itulah, Gubernur Anies meminta pemerintah pusat segera memberlakukan karantina wilayah. Meski begitu, Anies tetap mengusulkan agar sejumlah sektor usaha bisa bergerak. "Namun, di dalam usulannya itu, Anies juga meminta sejumlah sektor usaha tetap bergerak jika karantina wilayah benar-benar diberlakukan". Kalimat Kompas.com ini semakin menegaskan dukungan Kompas.com terhadap kebijakan Anies dengan menampilkan rancangan rencana Anies bila karantina diberlakukan. Untuk melengkapi sekaligus memperkuat keinginan karantina, Kompas.com mengutip pernyataan dari Menteri Koordinator Bidang Politik, Hukum dan Keamanan (Menko Polhukam) Mahfud MD yang menyatakan, surat permohonan karantina sudah diterima pemerintah pusat.
Dari elemen skrip, unsur (Who) bertambah dengan adanya narasumber Menteri Koordinator Bidang Politik, Hukum dan Keamanan (Menko Polhukam) Mahfud MD. Namun, unsur (Why), (How) tentang kenapa dan bagaimana penyebaran virus corona tipe 2 (SARS-CoV-2) penyebab Covid-19, tidak tampak dalam berita ini.

Dari elemen Tematik, tema utama yang ditekankan yakni, Anies meminta pemberlakuan karantina wilayah DKI Jakarta demi mencegah penyebaran virus corona tipe 2 (SARS-CoV-2) penyebab Covid-19.

Dalam isi beritanya, peneliti menemukan hubungan kalimat yang tidak memberikan kesimpulan 5 sektor usaha tetap bergerak bila karantina. Dalam isi beritanya juga ada upaya penyembunyian fakta, yang mengesankan seolah-olah permintaan Anies telah disetjui pemerintah Pusat. Perhatikan kalimat isi berita berikut ini,

"Pemerintah pusat sebelumnya menyatakan sudah menerima permintaan dari Anies untuk memberlakukan karantina wilayah di Ibu Kota. Hal tersebut diungkapkan Menteri Koordinator Bidang Politik, Hukum dan Keamanan (Menko Polhukam) Mahfud MD”.

Namun di kalimat selanjutnya Mahfud menuturkan, "Mahfud menuturkan, surat tertanggal 28 Maret 2020 diterima pada Minggu (29/3/2020)". Kalimat kedua ini membuktikan pemerintah pusat belum menyetujui permintaan soal karantina wilayah. Yang diterima itu baru surat permohonan saja. Apalagi pada paragraf selanjutnya, Mahfud MD yang menyatakan, permintaan karantina itu masih akan dibahas pada hari Selasa, 31 Maret 2020. Terlihat nyata, konstruksi kompas.com yang menginginkan karantina.

Dari elemen retoris, Kompas.com memberikan label kepada Mahfud MD dengan menonjolkan jabatan Menteri Koordinator Bidang Politik, Hukum dan Keamanan (Menko Polhukam) Mahfud MD, sebagai simbol pemerintah pusat. Cara ini dilakukan untuk melegitimasi bahwa sumber yang dikutip itu kredibel sehingga isi beritanya berbobot sekaligus representasi segmen masyarakat yang 
berbeda. Secara keseluruhan, teks berita ini mengarahkan permintaan Gubernur Anies agar dilakukan karantina wilayah Jakarta disetujui pemerintah pusat.

\section{Berita berjudul "Kewenangannya Terbatas, Anies Harap Ada Ketetapan untuk Penegakan Social Distancing"}

Dari analisis Sintaksis, latar informasi berita keempat ini mempertegas keinginan karantina wilayah DKI Jakarta. Seperti tiga berita sebelumnya, kembali Kompas.com menggunakan pernyataan Anies pada judulnya. Artinya, Kompas.com menggunakan sudut pandang pihak Anies Baswedan.

Dalam isi beritanya, tampak upaya Kompas.com untuk mengkonstruksi permintaan Anies kepada pemerintah pusat tentang karantina wilayah dengan kalimat berikut ini, "Hal ini seperti arahan Presiden Joko Widodo yang tercantum dalam UndangUndang Nomor 6 Tahun 2018 tentang Kekarantinaan Kesehatan".

Dengan kata "seperti arahan Presiden Joko Widodo", Kompas.com mengkonstruksi seolah keinginan Anies Baswedan tentang karantina wilayah itu sejalan dengan keinginan Presiden Joko Widodo.

Dari analisis stuktur Skrip, berita keempat Kompas.com tidak menjawab siapa dan berasal dari mana korban Covid-19 di Jakarta yang disebutkan di bagian penutup berita, juga kenapa kewenangan Anies terbatas, kenapa ada lima sektor usaha, dan bagaimana bila karantina jadi lakukan. Pada bagian penutup berita kali ini, Kompas.com memasukan data pasien positif corona di DKI Jakarta. Lagi-lagi Kompas.com tidak menjelaskan data ini datang darimana, korban berasal darimana, dan hanya mencantumkan 76 pasien meninggal dunia.

Dari analisis struktur Tematis, tema utama yang diusung adalah permintaan karantina wilayah DKI Jakarta pada pemerintah pusat. Hal ini terlihat pada kutipan berita di bawah ini, "Karena itulah kewenangannya terbatas, kita makanya berharap ada ketetapan hukum sehingga kita bisa melakukan penegakan atau enforcement," ucap Anies dalam konferensi pers di Balai Kota, Jakarta Pusat, yang disiarkan di Youtube Pemprov DKI, Senin (30/3/2020).

Kutipan pernyataan Anies ini menggambarkan, niat Anies melakukan karantina harus mengikuti keputusan pemerintah pusat.

Secara retoris, Kompas.com masih menggunakan cara serupa yaitu dengan cara Leksikon, yaitu memberi tekanan pada katakata 'demi', yang bermakna 'atas nama' mencegah penyebaran virus corona. Hal ini nampak dari kutipan berikut ini, "Anies juga telah meminta pemberlakuan karantina wilayah DKI Jakarta demi mencegah penyebaran virus corona".

\section{Berita berjudul "Lebih Besar dari Angka Kematian Nasional, 283 Jenazah di DKI Dimakamkan dengan Protokol Covid-19".}

Dari analisis Sintaksis, judul berita langsung membidik 283 jenazah di DKI Jakarta yang dimakamkan dengan protokol Covid-19 itu lebih besar dari jumlah angka kematian secara nasional. Munculnya pernyataan Anies dalam judul, menunjukkan Kompas.com hanya menggunakan satu sudut pandang saja. Berita ini kelanjutan dari berita ketiga dan keempat yang menyorot permintaan Anies Baswedan ke pemerintah pusat untuk karantina wilayah DKI Jakarta. Pernyataan Anies di judul, tidak terdapat dalam lead berita, tapi ada di paragraf 6 . Seperti ini kutipan beritanya, "Data 283 pemakaman jenazah dengan protokol pemulasaran jasad pasien Covid-19 itu lebih tinggi dibandingkan angka kematian nasional akibat Covid-19 yang dirilis pemerintah pusat". Kemudian Kompas.com menampilkan data sebagai berikut,"Hingga Senin pukul 12.00 WIB, diketahui ada 122 pasien meninggal dunia di Indonesia, setelah dinyatakan positif Covid-19". Selanjutnya dipaparkan,

"Berangkat dari angka 283 pemakaman 
jenazah tersebut, Pemprov DKI membuat perkiraan jumlah kasus positif Covid-19 di Jakarta. Bila angka 283 pemakaman itu dijadikan dasar menyusun perkiraan jumlah pasien positif di Ibu Kota, dengan case fatality rate tiga persen, maka potensi angka kasus positif Covid-19 di Jakarta per Maret 2020 sebanyak 9.430 kasus".

Pernyataan Anies yang membandingkan angka kematian di DKI Jakarta dengan tingkat kematian secara nasional membingungkan. Pasalnya, dalam berita sebelumnya, Anies menyebutkan bahwa 283 jenazah yang dimakamkan itu belum tentu Covid-19. Apalagi Kompas.com tidak melakukan verifikasi data yang sebenarnya atas penyebab kematian 283 jenazah tersebut.

Selanjutnya, Kompas.com menampilkan angka 122 pasien meninggal dunia setelah dinyatakan positif, tanpa menyebut dari mana angka kematian itu mereka peroleh. Ataukah itu hanya pernyataan Anies yang dikutip Kompas.com? Kompas.com juga tidak menjelaskan apa yang dimaksud dengan case fatality rate yang disampaikan Gubernur Anies.

Kompas.com mengutip utuh pernyataan Anies tanpa melakukan verifikasi atas data yang disampaikan. Padahal dalam dunia jurnalistik maupun jurnalisme bencana, verifikasi atas data yang diperoleh wajib dilakukan, agar khalayak tidak dibuat bingung. Berita kelima mempunyai dua sub judul yang diberi huruf tebal bertuliskan "Kasus positif Covid-19 di Jakarta" dan "Pentingnya pembatasan aktivitas".

Dari struktur Retoris, idiom "bergetar" ditampilkan lagi agar terkesan dramatis. Selain itu, ada label positif yang disematkan kepada Gubernur Anies Baswedan dengan memakai kata "eks Menteri Pendidikan dan Kebudayaan RI". Kompas.com melegitimasi Anies sebagai sumber yang kredibel dan cerdas untuk memberi bobot pada berita yang ditampilkan.

Dari 5 berita Kompas.com sebagai hasil konstruksi Konferensi Pers Gubernur DKI Jakarta Anies Baswedan, peneliti menemukan hal sebagai berikut:

\section{Sintaksis}

Dari lima judul berita Kompas.com dapat dilihat, Kompas.com menggunakan pernyataan Anies sebagai judul beritanya. Judul memiliki fungsi framing yang kuat untuk menggiring opini khalayak ke arah tertentu, selain menjadi pusat perhatian sebuah media massa.

Lead dan isi beritapun merupakan kutipan pernyataan Anies. Hal ini membuktikan, Kompas.com hanya menggunakan satu sudut pandang sekaligus cenderung mendukung kebijakan Gubernur Anies yang meminta karantina wilayah untuk mencegah penyebaran virus tentang Covid-19 di DKI Jakarta.

Adanya pernyataan Menteri Koordinator Bidang Politik, Hukum dan Keamanan (Menko Polhukam) Mahfud MD, mengesankan pemerintah sudah menyetujui permintaan Gubernur Anies untuk karantina wilayah. Padahal Mahfud MD menjelaskan, yang diterima itu baru surat permohonan Anies.

Kutipan data dari narasumber utama yang mendukung framing Kompas.com lebih dominan dibandingkan kutipan dari narasumber lain yaitu rilis Pemprov DKI Jakarta dan data dari Kementerian Kesehatan. Kompas.com tidak melakukan verifikasi kepada Kementerian Kesehatan, juga terhadap rilis Pemprov DKI Jakarta.

Padahal, dalam jurnalisme bencana, prinsip akurasi harus diutamakan. Penting bagi media melakukan check and recheck dan tidak boleh mengandalkan satu sumber informasi (Nazaruddin 2007).

\section{Skrip}

Dalam struktur Skrip, unsur 5W + $1 \mathrm{H}$ sudah lengkap. Namun, pemilihan unsurunsur kelengkapan teks berita, hanya mendukung tema atau konstruksi dari Kompas.com itu sendiri. Hal ini dapat dianggap sebagai upaya menyembunyikan fakta yang seharusnya diketahui oleh 
pembaca. Dan sebaliknya, upaya untuk menonjolkan suatu komponen pemberitaan merupakan salah satu cara untuk memberikan wacana tertentu kepada pembaca (Adila, 2012). Padahal, saat terjadi bencana, media harus menyediakan informasi dasar yang akurat tentang jenis dan sumber bencana serta cara-cara menyelamatkan diri. Dalam fase ini, media harus menjadi aktor utama yang meminimalisir beredarnya rumor yang meresahkan masyarakat. Jelas, prinsip akurasi pemberitaan menjadi normatif-etis paling dasar yang harus dipegang teguh media dan para pekerjanya. (Nazaruddin 2007).

\section{Tematik}

Lima tema yang mengemuka dalam 5 berita Kompas.com adalah: a) Pemakaman 283 jenazah di DKI Jakarta dengan protokol Covid19, selama bulan Maret 2020. Situasi Jakarta amat mengkhawatirkan; b) Tidak semua jenazah yang dimakamkan positif Covid-19; c) Data 283 pemakaman jenazah dengan protokol Covid-19 di DKI Jakarta lebih tinggi dibandingkan angka kematian nasional; d) Gubernur DKI Jakarta Anies Baswedan minta karantina wilayah; e) Warga Jakarta tetap di rumah, tidak berkerumun, menjaga penularan Covid-19.

Kompas.com memberi porsi minim atas informasi yang tidak sama dengan konstruksi berita konferensi pers tersebut. Meski dalam tekanan deadline, reporter dan redaksi wajib melakukan verifikasi data yang diperoleh untuk menghasilkan kepastian.

\section{Retoris}

Dari struktur retoris, wartawan menekankan fakta dengan penonjolan angka “283" dalam judul, lead atau isi berita dalam lima berita Kompas.com, karena penting untuk diketahui dan diingat pembaca. Begitupun dengan kata "amat mengkhawatirkan", memberi makna situasi Jakarta luar biasa mencekam.

Hight dan McMahon (2006) mengatakan bahwa dalam fase-fase awal paska bencana seringkali ada kabar angin yang sangat dramatis, misalnya angka kematian yang dibesar-besarkan, ketakutan dan kekacauan sosial. (Nazaruddin, 2012).

Cara lain yang dilakukan dari sisi retoris adalah penyebutan kata ganti Gubernur DKI Jakarta Anies Baswedan menjadi "eks Menteri Pendidikan dan Kebudayaan RI". Ini upaya legitimasi simbolik, bahwa sumber yang dikutip kredibel dan cerdas, dan berbobot.

\section{SIMPULAN}

Berdasarkan pengamatan tersebut, peneliti menyimpulkan bahwa Kompas.com mendukung kebijakan Gubernur Anies Baswedan melakukan karantina wilayah DKI Jakarta. Dalam mengkonstruksi konferensi pers tersebut, Kompas.com hanya melihat dan menggunakan satu sudut pandang saja, yakni dari Gubernur Anies. Pasalnya, dominasi Gubernur Anies sebagai nara sumber tunggal dalam lima pemberitaan Kompas.com tidak bisa dipungkiri. Lalu, Kompas.com juga tidak memenuhi prinsip akurasi dalam jurnalisme bencana, karena tidak melakukan verifikasi data yang diperoleh. Meski bekerja dalam tekanan deadline, Kompas.com harus tetap mengutamakan verifikasi sebagai bentuk sikap kritis terhadap data, agar terhindar dari kesan sebagai kepanjangan tangan pemerintah.

\section{DAFTAR PUSTAKA}

Ahmad Arif. (2010). Jurnalisme Bencana, Bencana Jurnalisme. Jakarta: Kepustakaan Popular Gramedia.

Alexa.com. (2020, 3 Juli). Top Sites in Indonesia. Diakses dari https://www.alexa.com/topsites/countr ies/ID).

Basrowi dan Sadikin. (2002). Metode Penelitian Perspektif Mikro: Grounded theory, Fenomenologi, Etnometodologi, Etnografi, Dramaturgi, Interaksi Simbolik, Hermeneutik, Konstruksi Sosial, Analisis Wacana, dan Metodologi Refleksi. Surabaya: Insan Cendekia. 
Bungin, Burhan. (2008). Konstruksi Sosial Media Massa. Jakarta: Kencana Prenada Media Group.

Eriyanto. (2001). Analisis Wacana: Pengantar Analisis Teks Media. Yogyakarta: LKiS.

Eriyanto. (2002). Analisis Framing: Konstruksi, Ideologi, dan Politik Media. Yogyakarta: LKiS.

Eriyanto. (2008). Konstruksi. Ideologi. dan Politik Media. Yogyakarta: LKiS

Eriyanto. (2012). Anlisis Framing: Komunikasi, Ideologi dan Politik Media. Yogyakarta: LKIS

Horsley, J.Suzanne (2016) "Media Framing of Disasters Implications for Disaster Response Communicators" dalam Andreas Schwarz, Matthew W.Seeger, Claudia Auer (Editor) The Handbook of International Crisis Communication Research. West Sussex : Wiley-Blackwell

Pemerintah Indonesia. (1999). Undang Undang No. 40 Tahun 1999 Tentang Pers. Lembaran RI Tahun 1999 No. 40. Jakarta: Sekretariat Negara.
Sanusi, H. (2018). Jurnalisme dan Bencana (Refleksi Peran Jurnalis dalam Liputan Bencana Gempa, Tsunami, dan Likuifaksi Palu-Donggala). Jurnalisa: Jurnal Jurusan Jurnalistik, 04 (2), 211225. https://doi.org/10.24252/jurnalisa.v $4 \mathrm{i} 2.6895$

Sobur, A. (2002). Analisis Teks Media: Suatu Pengantar Untuk Analisis Wacana, Analisis dan Framing. Bandung: PT Remaja Rosdakarya

Sobur, A. (2004). Semiotika Komunikasi. Bandung: PT Remaja Rosdakarya

Sumadiria, H. (2010). Jurnalistik Indonesia: Menulis Berita dan Feature. Bandung: Simbiosa Rekatama Media.

Sutedjo dan Sumarlam. (2008). Jurnalistik Plus 1: Kiat Merentas Media dengan Ceria. Depok: Nadi Pustaka.

Wahyuni, H. I. (2008). Kecenderungan "Framing" Media Massa Indonesia dalam Meliput Bencana sebagai Media Event. Jurnal Ilmu Sosial dan Ilmu Politik, 11(3), 307-330. doi:10.22146/jsp.10990.

World Health Organization. (2020). The World Health Report 2020. Geneva: WHO 